\title{
The effect of contrasting management types on two distinct taxonomic groups in a large-scaled windthrow
}

\author{
Michał Żmihorski • Ewa Durska
}

Received: 27 February 2010/Revised: 22 September 2010/Accepted: 20 October 2010/Published online: 19 November 2010

(C) The Author(s) 2010. This article is published with open access at Springerlink.com

\begin{abstract}
Improving ways of managing disturbed areas is in urgent need of further research. We assessed the effect of two contrasting management types - salvage logging and set aside for natural regeneration-applied to a large-scale windthrow in NE Poland on two distinct taxonomic groups of animals: scuttle flies and birds. In total, 5,368 individual scuttle flies were trapped and 1,649 individual birds were recorded. In both taxonomic groups, we recorded the "winners and losers" of the effects of salvage logging. The responses of particular species in both groups were independent of their body size. Species diversity, assessed by rarefaction, increased as a result of the logging in birds and declined in scuttle flies. The species richness, corrected for unseen species of scuttle flies and birds, was higher on the managed windthrow when compared to the natural one. Comparison of the results obtained with published data from the intact stands of Białowieża Primeval Forest suggests that salvage logging reduced the similarity of the fly and bird community to those reported from undisturbed, natural forest areas. Our results concern mostly the common species. We conclude that salvage logging has considerable influence on assemblages of common species in the postdisturbance forests. Birds and flies did not respond similarly to salvage logging in term of species diversity, although both groups included species that were attracted to either managed or unmanaged windthrow sites.
\end{abstract}

Communicated by J. Müller.

M. Żmihorski $(\bowtie) \cdot$ E. Durska

Museum and Institute of Zoology, Polish Academy of Sciences, Wilcza 64, 00-679 Warsaw, Poland

e-mail: zmihorski@miiz.waw.pl
Keywords Birds - Disturbances - Salvage logging · Scuttle flies $\cdot$ Windstorm

\section{Introduction}

Since the origins of forest management aimed at timber production, natural disturbances such as fires, windstorms, or outbreaks of folivorous insects have been regarded as undesirable. This view was driven by the fact that the disturbances can significantly reduce the quality and quantity of timber (Hanewinkel et al. 2008). Treatments applied by forest managers aimed at reducing the probability of the occurrence of natural disturbances (e.g., monitoring of folivorous insect populations, chemical protection against insects or fungi, removal of decaying trees and dead wood, regulations concerning fire prevention, and many others) have played an important role in forestry (Niemelä 1999). As a consequence, the role of disturbances and importance of disturbing agents (e.g., natural fires) in managed stands has been largely suppressed in comparison with those which are not managed (Kuuluvainen 2002).

However, the perception of natural disturbances in forest ecosystems has changed considerably during the last few decades (Niemelä 1999). The importance of disturbances as natural drivers of successional dynamics, stand development, and stand replacement has increasingly been stressed (Shorohova et al. 2009; Müller et al. 2010). Disturbances transform the closed-canopy structure of forests and create new habitats that are settled by many organisms atypical for closed stands (Fuller 2000). As a consequence, the species richness and species diversity of the disturbed patches may increase relative to intact stands (e.g., Faccio 2003). Moreover, great attention has recently been paid to 
mimic natural disturbances by newly developed harvesting techniques applied in managed stands (Niemelä 1999).

In light of this change in the perception of natural disturbances in the forest ecosystem, the current management practices in disturbed areas need to be evaluated. Silvicultural practices applied to disturbed areas most commonly rely on previous perceptions of disturbances as undesirable events and widely include salvage logging of damaged timber (Lindenmayer et al. 2008). Legislation supporting salvage logging in Poland is a good example of this conservative thinking irrespective of current knowledge in this field. Moreover, the paucity of research studies and recommendations concerning different management regimes applied in disturbed forests in Central Europe is becoming a problem and appears to contradict the extensive literature addressing this subject in other regions, e.g., North America, Scandinavia, and Germany (Lindenmayer et al. 2008 and references therein; Müller et al. 2010). Therefore, improving methods of forest management in disturbed areas is in urgent need of further study, especially as climate changes may affect the intensity of disturbances in the future (Schelhaas et al. 2003). In this study, we evaluate the effect of two contrasting management options applied in a large-scaled windthrow in Poland (Central Europe) on two distinct taxonomic groups of animals. We used scuttle flies (Diptera: Phoridae), trapping by yellow plastic pans, and birds (Aves), sampled with a fixed-radius point counts, as taxonomically distant and ecologically unrelated groups that are considered to be important in measuring the habitat quality and sustainable forest management (Venier and Pearce 2004; Disney and Durska 2008). Using these two groups of animals, we attempt to assess the biological consequences of salvage logging of the windthrow, which was applied in accordance with prescribed forest management regulations. We put forward hypothesis stating that despite distinct ecological differences between the studied groups, effect of salvage logging on scuttle flies and birds is similar.

\section{Materials and methods}

\section{Study area}

The study was conducted in north-eastern Poland, in the Pisz Forest, which is a ca. 90,000 ha forest complex. The Pisz Forest is located in a young glacial landscape with predominantly sandy soil, hence the prevailing forest associations are conifers. Its forest stands are covered by fresh coniferous stands (Peucedano-Pinetum, Matuszkiewicz 2001) managed for timber production and are composed mainly of pine (Pinus sylvestris), with a lower proportion of Norway spruce (Picea abies), and oak (Quercus robur).
Forest floor's vegetative understory is dominated by mosses (Polytrichum spp.), grasses (Deshampsia flexuosa), and shrubs (Vaccinium spp.).

On July 4, 2002 a windstorm (12 of Beaufort notation, wind speed up to $170 \mathrm{~km} / \mathrm{h}$ ) destroyed ca. 33,000 ha of stands in NE Poland and 15,000 ha in the Pisz Forest and created one of the largest windthrows ever recorded in Poland. In the Pisz area, total amount of dead wood denoted $12,000 \mathrm{~m}^{3}$. The forest was transformed into a mosaic of open areas (completely damaged stands covered ca. $40 \%$ of the windthrow area), partially destroyed stands with single trees or groups of trees and also small areas covered by undisturbed forest (ca. 10\% of the forest affected by the windstorm).

Field work was performed in two different habitats situated in the Pisz Forest. The habitats were natural windthrow allowed to regenerate naturally (hereafter natural windthrow) and managed windthrow where salvage logging was applied (hereafter managed windthrow, Fig. 1). The natural windthrow covered a 445-ha area, which had been excluded from post-disturbance salvage logging. This site abounded in fallen logs, leaning trees, and broken trunks, among which were numerous seedlings of pines, birches, and oaks (Fig. 1a). There were also some partially or completely undisturbed forest patches (up to several ha). The managed windthrow habitat covered an extensive part of the damaged forest, where all the fallen, leaning, and broken trees had been removed (Fig. 1b). In general, stands in the natural and managed windthrow were quite similar in term of pre-windthrow age structure and further windstorm damages. In the natural windthrow area, pre-windstorm age structure of the tree stand was as follows: age class $0-20$ years covered $49.0 \%$ of stands, class $21-40$ years$12.2 \%, 41-60$ years $-23.9 \%, 61-80$ years $-7.5 \%$, and $>80$ years $-7.3 \%$. Analogical values for the managed windthrow area denoted 57.9, 12.0, 10.0, 5.0, and 15.1\%, respectively (Zajączkowski and Dzierża 2007). In the natural windthrow, $4.3 \%$ of stands remain undisturbed (stands with no visible damages), $30.4 \%$ were partially damaged (up to $50 \%$ of trees damaged), and $65.3 \%$ were totally damaged (51-100\% of trees damaged). Analogical values for the managed windthrow area were similar and denoted $12.1,31.5$, and $56.5 \%$. In respect to age classes, disturbances in the two habitats were also similar: in natural windthrow, $12.2 \%$ of stands from 0 to 20 years age class were undamaged, whereas $62.6 \%$ were totally damaged. In managed windthrow, the proportion was similar: 20.2 and $62.0 \%$, respectively. In natural windthrow, $20.0 \%$ of the oldest stands ( $\geq 61$ years old) remain undamaged and $22.2 \%$ were totally damaged, and analogical values for the managed windthrow denoted 25.0 and $30.4 \%$, respectively (Zajączkowski and Dzierża 2007). The forest management activities on the managed windthrow started in 2002. In the 
Fig. 1 Two habitats in the Pisz Forest, NE Poland: natural windthrow left to regenerate naturally (fallen logs, leaning trees and broken trunks left) and managed windthrow (dead wood removed, artificial replanting applied). Both pictures were taken in 2007 , 5 years after the windstorm

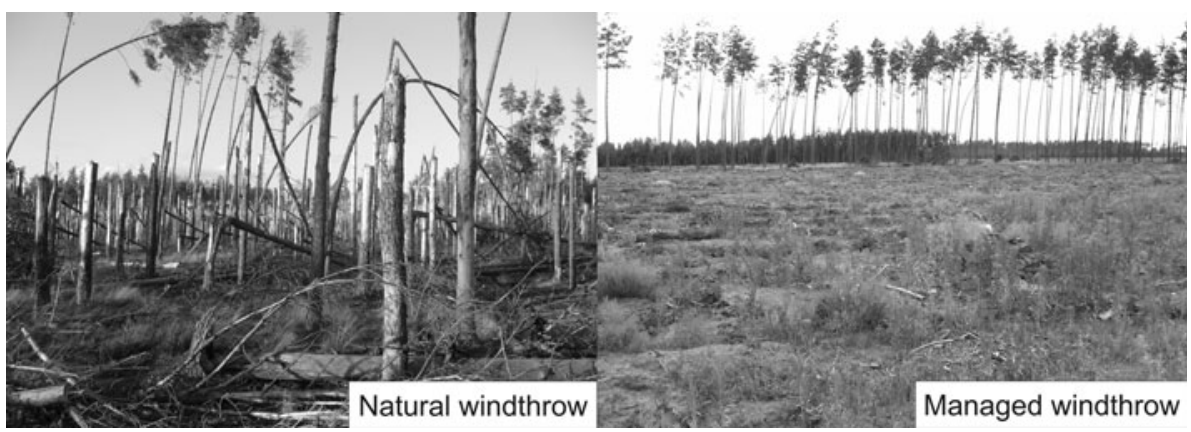

following years, most damaged stands were logged and replanted, in accordance with prescribed forest management regulations. A program of artificial replanting, partially fenced against ungulates, had been applied there. The natural and the managed windthrow habitats were adjacent to each other. For that reason, the sampling stations were arranged far from the edge of both habitats and sampling range was restricted in the case of birds (see below).

\section{Scuttle fly sampling}

Scuttle flies were collected (5,368 individuals) in 2005 at five sampling sites in managed windthrow and at 6 sampling sites in natural windthrow (Fig. 2). The trapping was continuous from May to September, with traps emptied every 3-4 weeks. We used yellow plastic pans, ca. $18 \mathrm{~cm}$

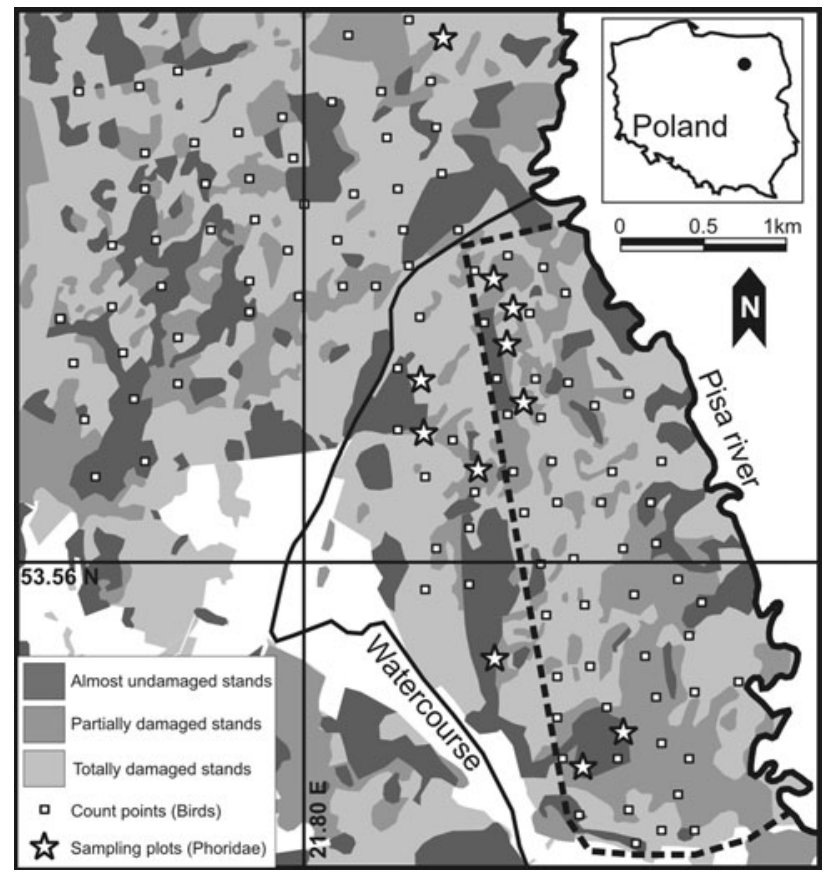

Fig. 2 The distribution of the sample stations for scuttle flies (stars) and birds (squares) in the natural windthrow (bordered with dashed line) and the managed windthrow (remaining area) in the Pisz forest. The gray color indicates the forest at different levels of damage and the white indicates open areas in diameter, containing a water solution of $75 \%$ ethylene glycol (for preserving the insects) and some detergent (surface active agent) (Bańkowska and Garbarczyk 1982). At each sampling site, flies were collected using three such traps (a total of 33 traps) situated one meter above the ground. Such placement of the pans reduces disturbance by small mammals, capture of slugs and others.

Identifications were made under a dissecting microscope with the material transferred to $75 \%$ ethanol. Analyses were based solely on male individuals (2,715 individuals) as most females of Megaselia spp. and Phora spp. are not identifiable to the species level. Consequently, these have only been identified to the genus level and are not included in the analysis. A lot of the Megaselia spp. males (about $10 \%$ ) were left unidentified because they were damaged and diagnostic features were no longer available. The keys of Disney (1983, 1989), Schmitz (1938-1958) and Schmitz et al. (1974-1981) were used for determinations. All materials from this study are deposited in the Museum and Institute of Zoology Polish Academy of Sciences in Warsaw and at the University of Cambridge.

\section{Bird sampling}

Bird counts were conducted in spring 2007. In the two habitats, we selected 106 census points (49 in the natural windthrow and 57 in the managed windthrow). Census points were selected at the intersections of a $300 \mathrm{~m} \times$ $300 \mathrm{~m}$ grid superimposed on the study area (the points were situated $300 \mathrm{~m}$ from one another, see also Ralph et al. (1995) who recommended $250 \mathrm{~m}$ between point counts as a minimum distance). The exact location of each point was marked with GPS (Fig. 2). Birds were counted using a fixed-radius point count (Gregory et al. 2004), which is one of the most common methods used for monitoring and ecological research of birds (see Gregory et al. 2007). At each point, we conducted two 10-min counts, one in April and one in June (Venier and Pearce 2007). This method allowed for the detection of both early sedentary breeders and tropical migrants that start to breed later in the spring. The points were sampled in a random order. During each 10-min count, we recorded all the individuals heard and 
seen within a radius of $100 \mathrm{~m}$ (Giraudo et al. 2008). In order to exclude migrants, we did not record birds flying above the canopy since they do not use windthrow being sampled (Faccio 2003). All counts were performed in the morning (before 10 a.m. in April and before 9 a.m. in June) and only in good weather conditions (no strong wind or rainfall). Of the two censuses carried out at a given point, the maximum number recorded for each species was used for further analysis (Barbaro et al. 2007).

\section{Statistical analysis}

We used redundancy analysis (RDA) implemented in CANOCO software (Lepš and Šmilauer 2003) in order to discriminate between species that show negative and positive response to the salvage logging. We used the locations of each sampling station (natural vs. managed windthrow) as an explanatory variable in RDA and performed the Monte Carlo test with 5,000 permutations for the assessment of the significance of the canonical axes (Lepš and Šmilauer 2003). We restricted the computation to only these species whose abundance in the two habitats pooled was equal to or exceeded ten individuals in order to exclude accidental species and to keep the output of the RDA as clear as possible.

We also investigated whether the response of each species to the salvage logging depended on its body size, since body mass- and size-related response to disturbances was previously reported for carabids and saproxylic beetles (Skłodowski 2006; Müller and Brandl 2009). For each species of scuttle fly and bird, we used scores for the first axis of the RDA as a measure of response to the logging. The location of a given species along the first axis of the RDA describes the importance of the habitat type (natural vs. managed windthrow) for the species distribution and abundance. As a measure of the body size of scuttle flies and birds, we adopted body length as a proxy (Schmitz 1938-1958; Schmitz et al. 1974-1981; Szczepski and Kozłowski 1953, respectively). Body length was then correlated with the RDA scores for flies and birds, respectively. In addition, we correlated body length with module of the RDA score to check whether species size is related to the strength of the response to the logging (irrespective of the direction of this response, i.e., positive or negative). SPSS 13.0 was used for the correlations.

We applied the rarefaction method in order to compare the diversity of scuttle fly and bird communities across the two habitats using EstimateS 800 software (Colwell 2005). We draw the expected cumulative species number as a function of the number of randomly chosen individuals, which should be interpreted as a measure of diversity (individual-based rarefaction, see Colwell 2005). Since bird density is higher in the natural windthrow relative to the managed windthrow (Żmihorski 2010), we used individual-based rarefaction that is independent of possible differences in mean number of individuals per sample between the comparing habitats (Gotelli and Colwell 2001). For this purpose, we used Coleman curves (Colwell 2005). We prepared the curves for each habitat type independently. Total species richness of scuttle flies and birds in the two habitats was also estimated. For this purpose, we used the abundance-based coverage estimator (ACE) that is corrected for species unseen in the samples (Chao et al. 2006). This method uses the abundance of rare species ( $P \leq 10$ individuals) in samples to estimate the number of unseen species and is commonly used in faunistic research (Chao et al. 2006).

Finally, for the discussion purposes, we also attempted to relative comparison the scuttle fly and bird communities recorded in our study to those reported from an intact, natural forest. For this purpose, we used the data available from Białowieża Forest as reference material. Białowieża Forest (BF), located ca. $150 \mathrm{~km}$ SE from the Pisz Forest, is a large woodland, the last surviving fragment of primeval temperate forest in the European lowland (Tomiałojc and Wesołowski 2004; Wesołowski 2005 and references therein). We used available data for scuttle flies from BF collected in 1986 and 1987 in BF (Durska 2001). As a reference for ornithological observations, we used the results of the long-term study on avifauna conducted by Tomiałojć and Wesołowski on the "NW" and "NE" plots (2004; see also Wesolowski et al. 2006 for detailed description and results). In the case of both groups, the reference material from $\mathrm{BF}$ was collected in intact, closedcanopy stands covering precisely the same forest association as in the Pisz Forest (i.e., Peucedano-Pinetum). In the case of birds, the methods differed (census in BF, point counts in Pisz Forest); however, this should not bias the results since we conducted relative comparison and put special attention to differences between the two types of windthrow rather than between $\mathrm{BF}$ and Pisz Forest. We used detrended correspondence analysis (DCA) implemented in CANOCO software to visualize the similarity of both taxonomic groups (in respect to species composition and abundance) in the managed and natural windthrow in the Pisz Forest in relation to those reported from the more natural and intact stands of Białowieża Forest.

\section{Results}

General characteristics of the two groups

In total, we recorded 2,715 scuttle fly male individuals representing 69 species (within two morphospecies: Megaselia pulicaria- complex and $M$. giraudii-complex) 
and 1,649 birds from 66 species. In the case of the scuttle flies, nine species of the genus Megaselia (M. verralli, M. pleuralis, Megaselia fumata, M. pusilla, M. pulicariacomplex, $M$. diversa, $M$. nigriceps, $M$. flavicoxa, M. altifrons), Borophaga femorata and Phora artifrons were the dominants ( $>10$ specimens in each habitat) in both habitats (Appendix 1). Most of the dominant species are known as open area species.

The chaffinch Fringilla coelebs was the most abundant bird species in both habitats. Three other species had at least one hundred individuals (when pooled for both habitats): the woodlark Lullula arborea, the great spotted woodpecker Dendrocopos major, and the tree pipit Anthus trivialis. Twenty-one bird species were recorded in only one habitat, and ten species were represented by only one individual (Appendix 2).

\section{Winners and losers}

Among the 26 scuttle fly species represented by at least ten individuals, exactly half were more common in the managed windthrow over the natural windthrow, while the remaining 13 showed an opposite tendency (Fig. 3). Megaselia verralli, $M$. pleuralis, $M$. propinqua, and Phora atra showed a distinct preference for the managed windthrow, while $M$. pulicaria-complex, M. subnudipennis, M. emarginata and M. ciliata preferred the left windthrow. The distribution of some species seemed to be independent of the salvage logging (e.g., Megaselia nigriceps). Megaselia speiseri was the one species with abundance exceeding $1 \%$ of the whole community without any captures on the natural windthrow, whereas M. hyalipennis showed reverse pattern. The distribution of scuttle fly species in relation to the canonical axes extracted by RDA was not random (Monte Carlo test, trace $=0.271$; $F$-ratio $=3.339 ; P=0.028)$.

The majority of bird species showed preferences for the natural windthrow. Among the 33 bird species included in the analysis (i.e., represented by at least ten individuals), 20 were recorded as being more abundant in the natural windthrow, while the remaining 13 showed the opposite tendency (Fig. 3). The skylark Alauda arvensis, the yellowhammer Emberiza citrinella, the wagtail Motacilla alba, and the woodlark Lullula arborea showed strong preferences for the managed windthrow. In contrast, the winter wren Troglodytes troglodytes, the spotted flycatcher Muscicapa striata, the blackcap Sylvia atricapilla, and the chiffchaff Phylloscopus collybita preferred the natural windthrow. The great tit Parus major, the tree pipit Anthus trivialis, and several other species showed no clear response to the salvage logging (Fig. 3). In general, the variability of bird abundances strongly depended on the canonical axes (Monte Carlo test, trace $=0.052 ; F$-ratio $=$ 5.665, $P=0.0002)$.

Body size versus response to the salvage logging

Preference for the managed or natural windthrow expressed as the species-specific score for the first axis of the RDA was correlated with the species body length neither in scuttle flies (Linear regression, $R^{2}=0.002 ; F=0.057$; $n=26 ; P=0.813$ ) nor in birds (Linear regression, $\left.R^{2}=0.018 ; \quad F=0.572 ; n=33 ; P=0.455\right)$. Also the strength of the response expressed as the module of the score for the first axis of the RDA showed no linear relationship with the body length of scuttle flies (Linear regression; $R^{2}=0.078 ; F=2.026 ; n=26 ; P=0.167$ ) or birds (Linear regression; $R^{2}=0.086 ; F=2.932 ; n=33$; $P=0.097)$.

Species diversity and species richness

The species diversity of scuttle fly communities expressed as cumulative number of fly species for a given number of randomly chosen individuals was higher in the natural windthrow when compared to the managed windthrow. For example, in order to record 53 fly species (the smallest number of species in one habitat), one had to collect 1,337 individuals in the managed windthrow or just 697 individuals in the natural windthrow (Fig. 4).

The species diversity of the bird community recorded in the natural windthrow was lower than in the managed windthrow. In order to see 52 bird species, one needed to record 853 randomly selected individuals in the natural windthrow or just 497 individuals in the managed windthrow (Fig. 4).

The total species richness corrected for unseen species was higher in the managed windthrow relative to the natural windthrow, both for scuttle flies (70.75 vs. 67.14 species, respectively) and for birds (73.17 vs. 56.91 species, respectively)(Fig. 5).

\section{Discussion}

Our analysis is based on data from only one windthrow, although occurring over a large area, is in fact one replication (sensu Hurlbert 1984). Therefore, the observed patterns of abundance of scuttle flies and birds in relation to management options should be treated with caution. However, studies concerning the effects of natural disturbances on wildlife are often based on limited material since the disturbances are spatially and temporally unpredictable (e.g., Faccio 2003; Grimbacher and Stork 2009). Moreover, pre-treatment (pre-windstorm) similarities in the forest 
Fig. 3 Ordination diagram of redundancy analysis (RDA) with 26 of the most common scuttle fly species (sampled 2005) and 33 of the most common bird species (sampled 2007) recorded in sampling stations in the Pisz Forest (NE Poland) explained by the placement of the stations in one of the two habitats: the managed windthrow and natural windthrow. The directions of the vectors along the horizontal axis show the preference for the two habitat types, vertical vectors indicate species not showing a preference for either habitat, the length of the vectors indicates the strength of the associations. Abbreviations of species names include the first three letters of the genus and species scientific names
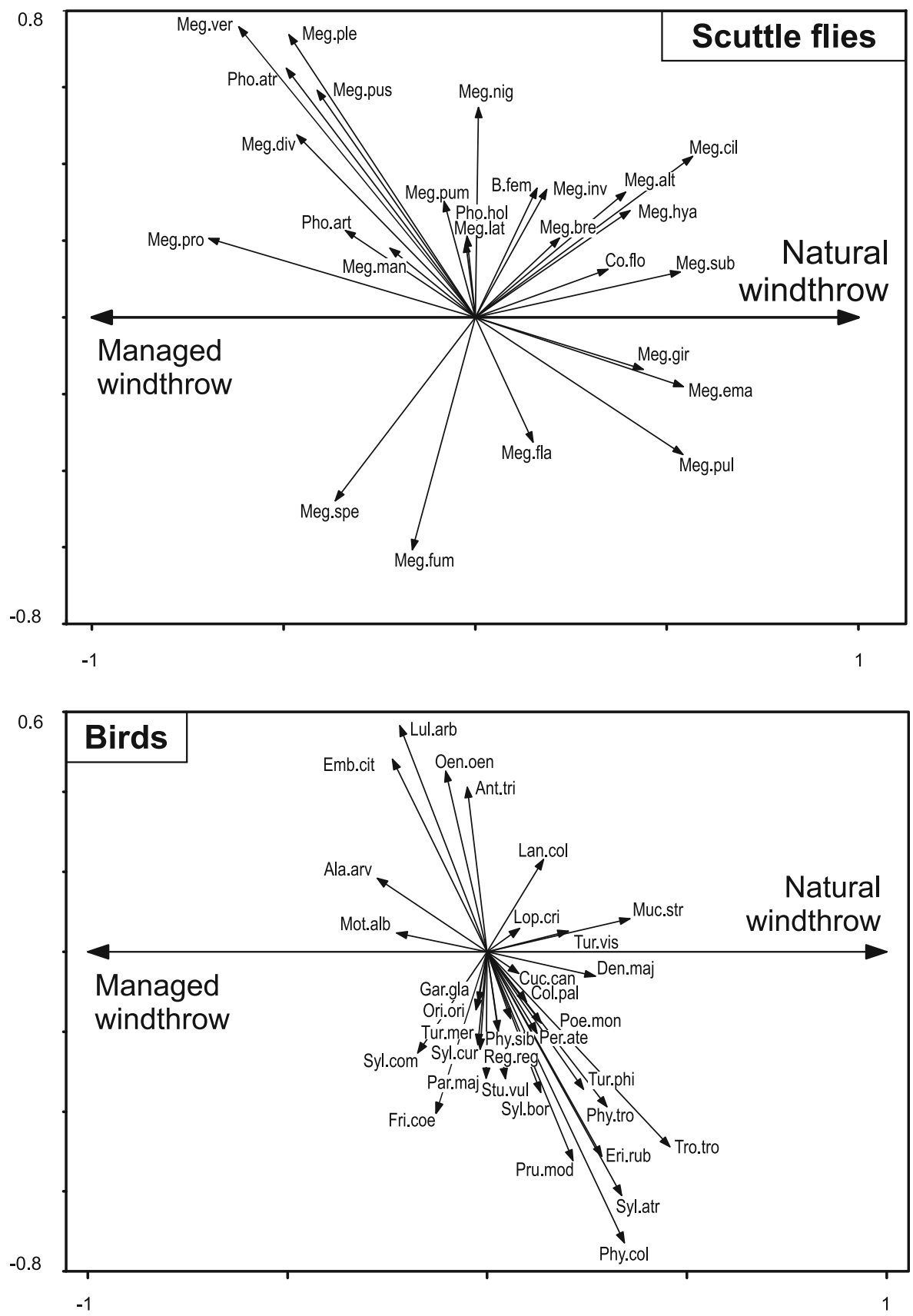

structure and habitat type of managed and natural plots allow us to assume that the patterns described in this study do in fact reflect the effect of the salvage logging.

The study confirms the results of previous work showing that Megaselia species make an extremely major contribution to communities of Phoridae (Disney 1994; Durska 1996, 2001, 2006, 2009). Two of the dominants in the scuttle fly communities of natural and managed windthrow (i.e., the pyrophilous Megaselia verralli and the polysaprophagous M. brevicostalis) are also dominants in other forests of the Polish Lowland (Durska 2006, 2009). The bird community recorded during the study was composed mainly of small passerines. We did not collect detailed data on large species, e.g., diurnal and nocturnal raptors. Also we did not record very rare species, e.g., rare woodpeckers, which possibly could be present in the windthrow in the Pisz Forest. This may be due to the method used-fixed-radius point count, as rare and shy species are difficult to detect with this method (Gregory et al. 2004). It should also be noted that the size of the natural windthrow (445 ha) may be less than is required by some species, such as raptors or galliform birds. Hence, the obtained results may not be reliable for all bird species and the effect of the salvage logging on rare species needs more detailed analysis. 

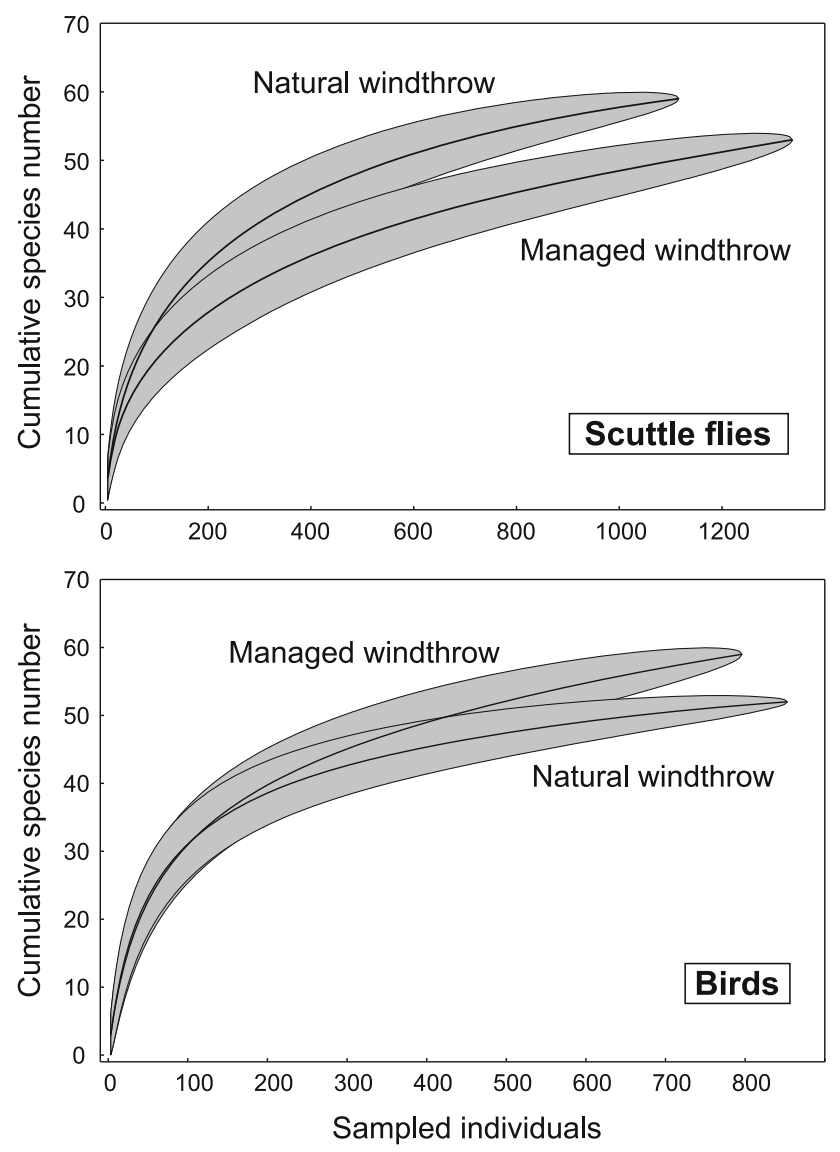

Fig. 4 The expected cumulative number of scuttle fly species and bird species (solid lines, $2 \times \mathrm{SD}$ bounds marked in gray) as a function of the number of sampled individuals in two habitat types (i.e., managed windthrow and natural windthrow)

In both taxonomic groups, one may identify the "winners" and "losers" of the salvage logging. This highly diversified reaction for different disturbing regimes or silvicultural treatments seems to be a common pattern (Greenberg and Lanham 2001; Venier and Pearce 2007; Kolbin 2008; Grimbacher and Stork 2009; Żmihorski 2010). In general, it seems that dead wood and natural structure of the windthrow left for natural regeneration positively affected forest dwelling species and saproxylic organisms (Bässler and Müller 2010; Müller et al. 2010), whereas abundance of open-area specialists increased as a result of windthrow management. Moreover, the response of scuttle flies and birds recorded in this study may indicate that leaving disturbed forest for natural regeneration has positive effect on forest specialists and saproxylic species in other taxonomic groups. In the case of scuttle flies, three of the dominant species in the Pisz Forest-Megaselia verralli, $M$. pleuralis and $M$. pulicaria-complex, are known as dominants in heterogeneous habitats afflicted by wildfires (a chestnut-belt in the Swiss Alps-Prescher et al. 2002) and in the pine plantations in Poland (Durska

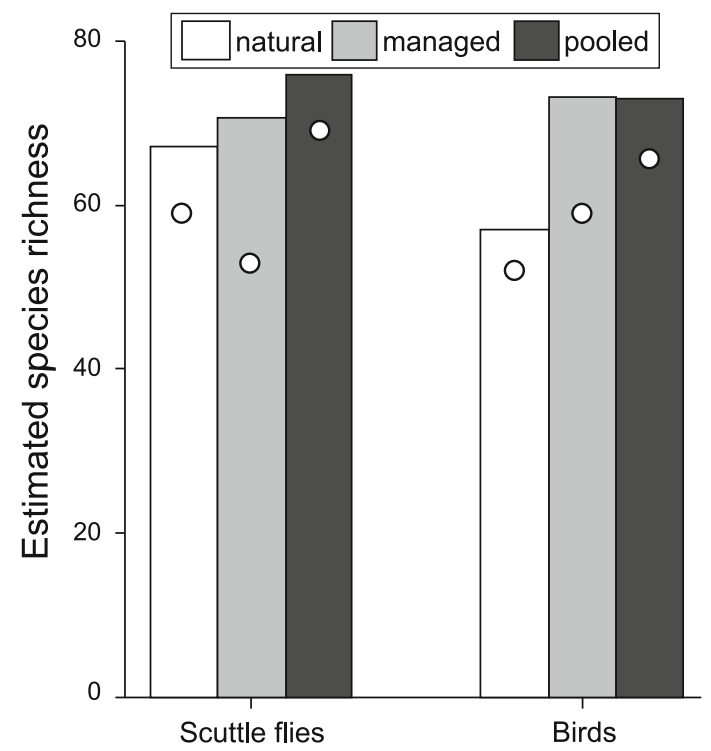

Fig. 5 Estimate of the total species richness of scuttle flies and birds in the two habitat types in the Pisz Forest. Bars denote the abundancebased coverage estimates (ACE) of a total species richness corrected for species unseen in the samples. Dots denote observed species richness

2001, 2006, 2009). However, the "disturbance specialists" Megaselia verralli and $M$. pleuralis preferred a managed windthrow over the natural one, whereas M. pulicariacomplex showed the opposite tendency. Our study reconfirms the results of previous work showing that Megaselia species, and especially these three open-area dominants mentioned above, make a major contribution to the communities of Phoridae after disturbance or stress (Durska 2009). In the case of birds, it seems that forest dwellers were more attracted by the natural windthrow, whereas species associated with open habitats preferred the managed windthrow. For instance, the winter wren, the great spotted woodpecker, and the blackcap, which showed strong preference for the natural windthrow, inhabit forests, whereas the skylark, the wagtail, and the yellowhammer, which preferred logged plot, are more typical for open or edge habitats (e.g., Moning and Müller 2008). Moreover, among six birds using tree holes for breeding (tits and the woodpecker), five preferred the natural windthrow, while the remaining one, the great tit, showed no clear preferences (see Fig. 4). Similar results were obtained by Germaine et al. (1997); Hutto and Gallo (2006); Koivula and Schmiegelow (2007). The authors recorded that postdisturbance harvesting negatively affected cavity-nesting birds; however, the effect of windstorm and its management on food resources of birds cannot be excluded.

We revealed clear transformation of scuttle fly and bird communities in response to the salvage logging. This result shows that the management of the disturbed plot had a strong impact on the wildlife characteristics of the 
disturbed habitat. It should be stressed that the impact of logging is independent of the disturbing agent (i.e., windstorm) - in our case, both plots were disturbed in the same way. This effect of logging of the windthrow on the two taxonomic groups confirms that post-disturbance harvesting considerably affects the ecosystem (Lindenmayer and Noss 2006; Koivula and Spence 2006).

We did not find a significant relationship between the body size of scuttle flies and birds and the response to the logging. Skłodowski (2006) found that clear-cutting caused a drastic decrease in mean individual biomass in carabids in the forest of Białowieża and this response to disturbances seems to be common in carabids (Ribera et al. 2001). However, our results do not necessarily stand in contradiction to the findings of Skłodowski (2006) since he analyzed the effect of disturbance while our study concentrates on post-disturbance treatments. It is worth adding that almost all specimens of scuttle flies species recorded on the windthrow were clearly smaller $(<2.5 \mathrm{~mm})$ than the species previously recorded in the intact old-growth stands of the Polish Lowland (Durska 1996).

Characteristics of the natural windthrow were similar to those reported from natural conditions (dead wood, natural regeneration, etc.) while these of the logged plot were much more artificial. Despite this, we observed two opposite patterns of species diversity as a response to the salvage logging. Species diversity increased in birds while it decreased in scuttle flies as a reaction to the post-disturbance harvesting. Flies were counted 3 years and birds 5 years after the windstorm event; however, the two periods covered very similar stage of forest regeneration, and therefore, we believe that the differences did not contribute to the observed differences in ecological response of the studied communities. This discrepancy partially supports former research showing that the diversity of one group is often a poor predictor of diversity in another (e.g., Davis et al. 2008 but see also Taboada et al. 2010). This finding seems to be important for the management of disturbances and one may conclude that species diversity is not a precise measure of the natural state of the habitat (Neumann and Starlinger 2001). Use of species diversity for assessment of the natural state may lead to contradictory conclusions and the final outcome depends strongly on the taxonomic groups taken into account. Estimated species richness should also be treated with caution when used as an important factor of habitat value: the estimated species richness of scuttle flies and birds was higher for the managed windthrow when compared to the natural windthrow. Again, this result suggests that species richness is not a universal indicator of the natural state of the habitat (Standovar et al. 2006). On the basis of the result, one may conclude that natural disturbances are not necessarily associated with higher species richness and species diversity relative to anthropogenic forest transformations. This in turn means that we failed to confirm our hypothesis concerning similar response of two distinct taxonomic groups for the salvage logging.

DCA showed that in respect to species composition of the scuttle fly community, the distance between the natural windthrow and the Białowieża Forest was less than that between the managed windthrow and BF (Fig. 6). A similar pattern was observed in birds. Bird species composition recorded in $\mathrm{BF}$ displayed greater similarity to that reported from the natural windthrow than to that computed for the managed windthrow (Fig. 6).

Comparison of our data to those available from the Białowieża Forest (BF) should be treated with caution because of some methodological differences and could be
Fig. 6 Position of four samples (managed windthrow, natural windthrow, and two samples from Białowieża Forest) of scuttle flies (upper) and birds (lower) along the first two axes of detrended correspondence analysis (DCA)
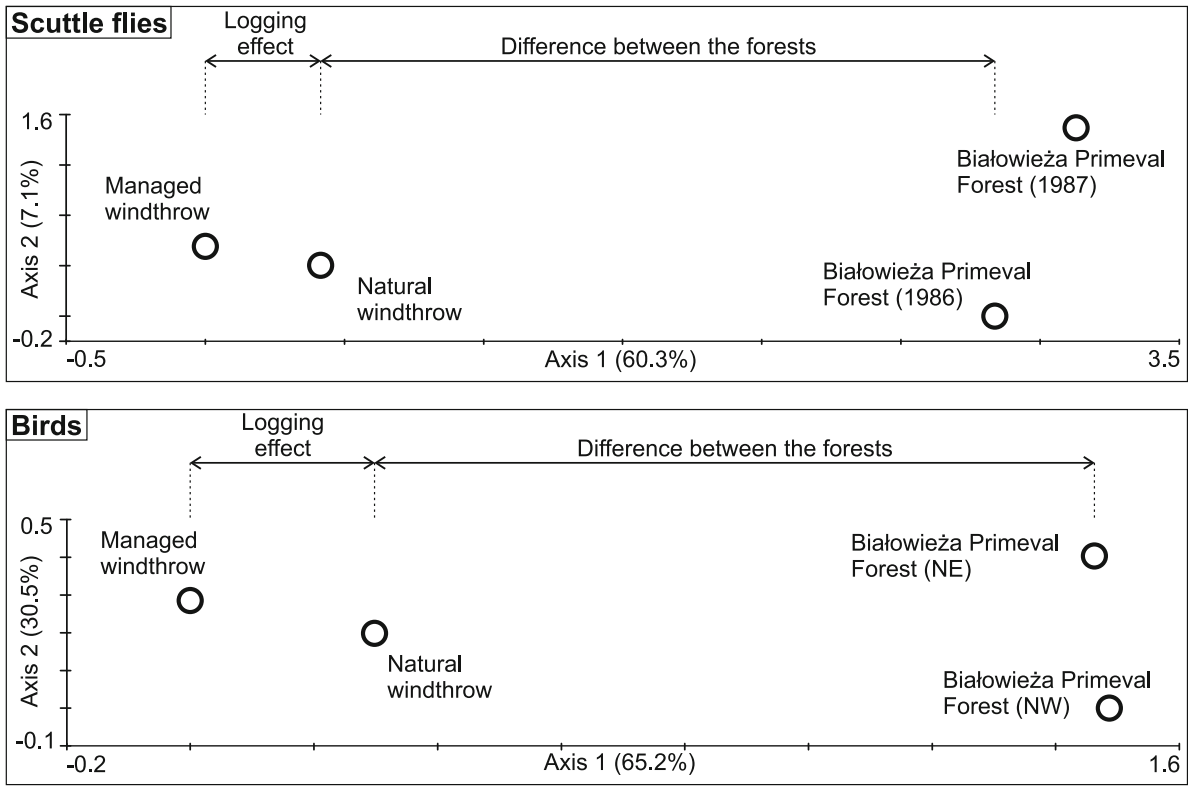
used as a suggestion for further research. Despite this, the comparison leads to several important conclusions. First, the species composition of scuttle fly and bird communities in the two forest complexes differs. The difference can be due to a higher level of anthropogenic transformation in the Pisz Forest when compared to the BF. Moreover, the difference between the forest complexes may partially result from the windstorm since both habitats in the Pisz Forest were disturbed, while sample sites from the BF were intact. Therefore, one may interpret the difference between the forests along the first axis of DCA (besides possible effect of methodology and temporal separation of the data sets) as the windstorm effect and the difference between the stands. The second, and most important, DCA showed that communities from the natural conditions (BF) were more similar to those reported from the natural windthrow left for natural regeneration than to those recorded in the managed windthrow. In other words, salvage logging applied in the windthrow reduced the similarity of scuttle fly and bird communities found there to those in intact stands in a largely natural state (see also Żmihorski 2010). It should be underlined that the general aim of the salvage logging was to facilitate and hasten the regeneration of the forest (see also Lindenmayer et al. 2008). However, in light of our results, the post-disturbance harvesting, instead of hastening the regeneration of the forest ecosystem, reduces its similarity (expressed as bird and scuttle fly communities) to the intact forest. It is worth noting that the effect of the salvage logging is independent of the windstorm effect. As a result, the plot affected by the windstorm followed by the salvage logging displays less similarity to the natural stands in BF than the plot affected by the windstorm only.

Acknowledgments We are grateful to Prof. Jerzy Gutowski for the materials concerning flies. We would like to thank Dr. R. Henry L. Disney for determining some problematic scuttle fly species and also thank Krzysztof Gagla, M.Sc., for his invaluable assistance with the segregation of the material. We gratefully acknowledge valuable comments on the manuscript made by Prof. Joanna Gliwicz and by two anonymous referees. Ewa Durska has benefited from SYNTHESYS support made available by the European Community-Research Infrastructure Action under the FP6 Structuring the European Area Programme AT-TAF 543 and SE-TAF 1833, while Michał Żmihorski was supported by grant BLP-278 from the Polish State Forests National Forest Holding. Graham Carr kindly improved the English.

Open Access This article is distributed under the terms of the Creative Commons Attribution Noncommercial License which permits any noncommercial use, distribution, and reproduction in any medium, provided the original author(s) and source are credited.

\section{Appendix 1}

See Table 1.
Table 1 Percentage of number of individuals of scuttle fly (Diptera: Phoridae) species (males only) recorded for 2005 in the natural windthrow and the managed windthrow in the Pisz Forest, NE Poland

\begin{tabular}{|c|c|c|c|}
\hline \# & Species & $\begin{array}{l}\text { Natural } \\
\text { windthrow }\end{array}$ & $\begin{array}{l}\text { Managed } \\
\text { windthrow }\end{array}$ \\
\hline 1 & Megaselia pulicaria-complex & 22.60 & 3.90 \\
\hline 2 & Megaselia verralli (Wood, 1910) & 14.86 & 29.87 \\
\hline 3 & Megaselia fumata (Malloch, 1909) & 7.59 & 7.59 \\
\hline 4 & $\begin{array}{l}\text { Megaselia subnudipennis (Schmitz, } \\
\text { 1919) }\end{array}$ & 4.23 & 0.27 \\
\hline 5 & Megaselia nigriceps (Loew, 1866) & 3.99 & 2.80 \\
\hline 6 & Megaselia pleuralis (Wood, 1909) & 3.35 & 12.99 \\
\hline 7 & Phora artifrons Schmitz, 1920 & 3.35 & 5.88 \\
\hline 8 & Megaselia flavicoxa (Zetterstedt, 1848) & 3.12 & 1.37 \\
\hline 9 & Borophaga femorata (Meigen, 1830) & 2.48 & 1.30 \\
\hline 10 & Megaselia altifrons (Wood, 1909) & 2.40 & 1.23 \\
\hline 11 & Megaselia giraudii-comlpex & 1.68 & 0.34 \\
\hline 12 & Megaselia pusilla (Meigen, 1830) & 1.60 & 3.96 \\
\hline 13 & Megaselia hyalipennis (Wood, 1912) & 1.44 & 0.00 \\
\hline 14 & Megaselia brevicostalis (Wood, 1910) & 1.28 & 0.62 \\
\hline 15 & Megaselia diversa (Wood, 1909) & 1.20 & 2.80 \\
\hline 16 & Megaselia emarginata (Wood, 1908) & 1.20 & 0.07 \\
\hline 17 & Conicera floricola Schmitz, 1938 & 0.96 & 0.34 \\
\hline 18 & Megaselia ciliata (Zetterstedt, 1848) & 0.80 & 0.21 \\
\hline 19 & Megaselia pumila (Meigen, 1830) & 0.80 & 0.68 \\
\hline 20 & Megaselia latifrons (Wood, 1910) & 0.72 & 0.55 \\
\hline 21 & Megaselia involuta (Wood, 1910) & 0.64 & 0.21 \\
\hline 22 & Megaselia manicata (Wood, 1910) & 0.64 & 0.68 \\
\hline 23 & Phora holosericea Schmitz, 1920 & 0.64 & 0.48 \\
\hline 24 & $\begin{array}{l}\text { Borophaga carinifrons (Zetterstedt, } \\
\text { 1848) }\end{array}$ & 0.56 & 0.00 \\
\hline 25 & Megaselia longicostalis (Wood, 1912) & 0.48 & 0.07 \\
\hline 26 & Metopina oligoneura (Mik, 1867) & 0.48 & 0.21 \\
\hline 27 & Megaselia elongata (Wood, 1914) & 0.40 & 0.27 \\
\hline 28 & Megaselia minor (Zetterstedt, 1848) & 0.40 & 0.07 \\
\hline 29 & Anevrina thoracica (Meigen, 1804) & 0.32 & 0.07 \\
\hline 30 & Conicera tarsalis Schmitz, 1920 & 0.32 & 0.00 \\
\hline 31 & Conicera tibialis Schmitz, 1925 & 0.32 & 0.27 \\
\hline 32 & Megaselia coccyx Schmitz, 1965 & 0.32 & 0.00 \\
\hline 33 & Megaselia spinicincta (Wood, 1910) & 0.32 & 0.00 \\
\hline 34 & Borophaga subsultans (Linné, 1767) & 0.24 & 0.21 \\
\hline 35 & Conicera dauci (Meigen, 1830) & 0.24 & 0.00 \\
\hline 36 & Megaselia campestris (Wood, 1908) & 0.24 & 0.07 \\
\hline 37 & Megaselia lata (Wood, 1910) & 0.24 & 0.27 \\
\hline 38 & Pseudacteon fennicus Schmitz, 1927 & 0.24 & 0.07 \\
\hline 39 & Conicera similis (Haliday, 1833) & 0.16 & 0.27 \\
\hline 40 & Megaselia breviseta (Wood, 1912) & 0.16 & 0.00 \\
\hline 41 & Megaselia curvicapilla Schmitz, 1947 & 0.16 & 0.00 \\
\hline 42 & Megaselia propinqua (Wood, 1909) & 0.16 & 1.71 \\
\hline 43 & Megaselia styloprocta (Schmitz, 1921) & 0.16 & 0.00 \\
\hline
\end{tabular}


Table 1 continued

\begin{tabular}{|c|c|c|c|}
\hline \# & Species & $\begin{array}{l}\text { Natural } \\
\text { windthrow }\end{array}$ & $\begin{array}{l}\text { Managed } \\
\text { windthrow }\end{array}$ \\
\hline 44 & Megaselia tarsalis (Wood, 1910) & 0.16 & 0.00 \\
\hline 45 & Megaselia unicolor (Schmitz, 1919) & 0.16 & 0.34 \\
\hline 46 & Phora atra (Meigen, 1804) & 0.16 & 3.21 \\
\hline 47 & Phora obscura (Zetterstedt, 1848) & 0.16 & 0.00 \\
\hline 48 & Triphleba papillata (Wingate, 1906) & 0.16 & 0.21 \\
\hline 49 & Anevrina unispinosa (Zetterstedt, 1860) & 0.08 & 0.07 \\
\hline 50 & Megaselia aculeata (Schmitz, 1919) & 0.08 & 0.07 \\
\hline 51 & Megaselia affinis (Wood, 1909) & 0.08 & 0.07 \\
\hline 52 & Megaselia albicans (Wood, 1908) & 0.08 & 0.00 \\
\hline 53 & Megaselia coei (Schmitz, 1938) & 0.08 & 0.00 \\
\hline 54 & Megaselia hibernans (Schmitz,1934) & 0.08 & 0.00 \\
\hline 55 & Megaselia hilaris Schmitz, 1927 & 0.08 & 0.00 \\
\hline 56 & Megaselia picta (Lehmann, 1822) & 0.08 & 0.07 \\
\hline 57 & Megaselia protarsalis Schmitz, 1927 & 0.08 & 0.00 \\
\hline 58 & Triphleba intermedia (Malloch, 1908) & 0.08 & 0.07 \\
\hline 59 & Triphleba opaca (Meigen, 1830) & 0.08 & 0.14 \\
\hline 60 & Anevrina curvinervis (Becker, 1901) & 0.00 & 0.07 \\
\hline 61 & Megaselia basispinata (Lundbeck, 1920) & 0.00 & 0.07 \\
\hline 62 & Megaselia flava (Fallen, 1823) & 0.00 & 0.27 \\
\hline 63 & Megaselia gregaria (Wood, 1910) & 0.00 & 0.07 \\
\hline 64 & Megaselia meconicera (Speiser, 1925) & 0.00 & 0.14 \\
\hline 65 & Megaselia scutellaris (Wood, 1909) & 0.00 & 0.41 \\
\hline 66 & Megaselia speiseri (Schmitz, 1929) & 0.00 & 4.24 \\
\hline 67 & Megaselia stigmatica (Schmitz, 1920) & 0.00 & 0.07 \\
\hline 68 & Megaselia subpleuralis (Wood, 1909) & 0.00 & 0.07 \\
\hline \multirow[t]{3}{*}{69} & Phora dubia (Zetterstedt, 1848) & 0.00 & 0.07 \\
\hline & Megaselia spp. (males) & 10.86 & 8.61 \\
\hline & Total individuals & 1,252 & 1,463 \\
\hline
\end{tabular}

Dominant species (with abundance exceeding $1 \%$ of overall community) are shown in bold type

\section{Appendix 2}

See Table 2.

Table 2 Percentage of number of individuals of bird species recorded in the natural windthrow and the managed windthrow in the Pisz Forest, NE Poland

\begin{tabular}{llcc}
\hline$\#$ & Species & $\begin{array}{l}\text { Natural } \\
\text { windthrow }\end{array}$ & $\begin{array}{l}\text { Managed } \\
\text { windthrow }\end{array}$ \\
\hline 1 & Fringilla coelebs & 11.37 & 15.70 \\
2 & Dendrocopos major & 7.39 & 5.53 \\
3 & Erithacus rubecula & 6.10 & 4.65 \\
4 & Phylloscopus trochilus & 5.98 & 3.89 \\
5 & Phylloscopus collybita & 5.98 & 3.02 \\
6 & Turdus philomelos & 5.28 & 3.89 \\
\hline
\end{tabular}

Table 2 continued

\begin{tabular}{|c|c|c|c|}
\hline$\#$ & Species & $\begin{array}{l}\text { Natural } \\
\text { windthrow }\end{array}$ & $\begin{array}{l}\text { Managed } \\
\text { windthrow }\end{array}$ \\
\hline 7 & Anthus trivialis & 5.16 & 7.04 \\
\hline 8 & Troglodytes troglodytes & 4.81 & 0.88 \\
\hline 9 & Lullula arborea & 4.57 & 8.79 \\
\hline 10 & Prunella modularis & 3.87 & 2.39 \\
\hline 11 & Lanius collurio & 3.05 & 2.39 \\
\hline 12 & Sylvia atricapilla & 3.05 & 0.88 \\
\hline 13 & Garrulus glandarius & 2.93 & 3.89 \\
\hline 14 & Emberiza citrinella & 2.81 & 6.53 \\
\hline 15 & Muscicapa striata & 2.34 & 0.38 \\
\hline 16 & Parus major & 1.99 & 2.51 \\
\hline 17 & Turdus merula & 1.76 & 2.39 \\
\hline 18 & Turdus viscivorus & 1.76 & 0.88 \\
\hline 19 & Lophophanes cristatus & 1.41 & 1.26 \\
\hline 20 & Poecile montanus & 1.41 & 0.88 \\
\hline 21 & Oenanthe oenanthe & 1.29 & 2.64 \\
\hline 22 & Phylloscopus sibilatrix & 1.29 & 1.26 \\
\hline 23 & Periperus ater & 1.29 & 0.88 \\
\hline 24 & Sturnus vulgaris & 1.17 & 1.13 \\
\hline 25 & Sylvia communis & 1.06 & 2.64 \\
\hline 26 & Cuculus canorus & 0.94 & 0.75 \\
\hline 27 & Columba palumbus & 0.94 & 0.63 \\
\hline 28 & Sylvia borin & 0.94 & 0.50 \\
\hline 29 & Sylvia curruca & 0.82 & 1.13 \\
\hline 30 & Regulus regulus & 0.82 & 0.88 \\
\hline 31 & Dryocopus martius & 0.82 & 0.25 \\
\hline 32 & Certhia familiaris & 0.70 & 0.13 \\
\hline 33 & Oriolus oriolus & 0.59 & 0.88 \\
\hline 34 & Phoenicurus phoenicurus & 0.59 & 0.00 \\
\hline 35 & Corvus corax & 0.47 & 0.25 \\
\hline 36 & Poecile palustris & 0.35 & 0.00 \\
\hline 37 & Alauda arvensis & 0.23 & 2.26 \\
\hline 38 & Pyrrhula pyrrhula & 0.23 & 0.25 \\
\hline 39 & Uрира ерорs & 0.23 & 0.13 \\
\hline 40 & Jynx torquila & 0.23 & 0.13 \\
\hline 41 & Anas platyrhynchos & 0.23 & 0.13 \\
\hline 42 & Streptopelia turtur & 0.23 & 0.13 \\
\hline 43 & Hippolais icterina & 0.23 & 0.13 \\
\hline 44 & Loxia curvirostra & 0.23 & 0.00 \\
\hline 45 & Buteo buteo & 0.23 & 0.00 \\
\hline 46 & Accipiter nisus & 0.12 & 0.25 \\
\hline 47 & Tringa ochropus & 0.12 & 0.25 \\
\hline 48 & Turdus pilaris & 0.12 & 0.13 \\
\hline 49 & Lanius excubitor & 0.12 & 0.13 \\
\hline 50 & Carduelis spinus & 0.12 & 0.00 \\
\hline 51 & Dendrocopos minor & 0.12 & 0.00 \\
\hline 52 & Cyanistes caeruleus & 0.12 & 0.00 \\
\hline 53 & Motacilla alba & 0.00 & 1.51 \\
\hline
\end{tabular}


Table 2 continued

\begin{tabular}{llcc}
\hline$\#$ & Species & $\begin{array}{l}\text { Natural } \\
\text { windthrow }\end{array}$ & $\begin{array}{l}\text { Managed } \\
\text { windthrow }\end{array}$ \\
\hline 54 & Gallinago gallinago & 0.00 & 0.50 \\
55 & Anthus pratensis & 0.00 & 0.38 \\
56 & Corvus corone & 0.00 & 0.38 \\
57 & Fringilla montifringilla & 0.00 & 0.25 \\
58 & Falco subbuteo & 0.00 & 0.25 \\
59 & Ficedula hypoleuca & 0.00 & 0.25 \\
60 & Turdus iliacus & 0.00 & 0.13 \\
61 & Carduelis chloris & 0.00 & 0.13 \\
62 & Coccothraustes coccothraustes & 0.00 & 0.13 \\
63 & Aquila pomarina & 0.00 & 0.13 \\
64 & Saxicola rubetra & 0.00 & 0.13 \\
65 & Miliaria calandra & 0.00 & 0.13 \\
66 & Columba oeans & 0.00 & 0.13 \\
& Total individuals & 853 & 796 \\
\hline
\end{tabular}

Dominant species (with abundance exceeding $1 \%$ of overall community) are marked in bold

\section{References}

Bańkowska R, Garbarczyk H (1982) Charakterystyka terenów badań oraz metod zbierania i opracowywania materiałów. In: Zoocenologiczne podstawy kształtowania środowiska przyrodniczego osiedla mieszkaniowego Białołęka Dworska w Warszawie. Part I. Skład gatunkowy i struktura fauny terenu projektowanego osiedla mieszkaniowego. Fragmenta Faunistica 26:17-26

Barbaro L, Rossi JP, Vetillard F, Nezan J, Jactel H (2007) The spatial distribution of birds and carabid beetles in pine plantation forests: the role of landscape composition and structure. J Biogeogr 34:652-664

Bässler C, Müller J (2010) Importance of natural disturbance for recovery of the rare polypore Antrodiella citronella Niemelä \& Ryvarden. Fungal Biol 114:129-133

Chao A, Li PC, Agatha S, Foissner W (2006) A statistical approach to estimate soil ciliate diversity and distribution based on data from five continents. Oikos 114:479-493

Colwell RK (2005) Estimates: statistical estimation of species richness and shared species from samples. Version 7.5. http://www.purl.oclc.org/estimates. Assessed 20 December 2010

Davis JD, Hendrix SD, Debinski DM, Hemsley CJ (2008) Butterfly, bee and forb community composition and cross-taxon incongruence in tallgrass prairie fragments. J Insect Conserv 12:69-79

Disney RHL (1983) Scuttle flies. Diptera: Phoridae (except Megaselia). Handb Identif Br Insects 10:1-81

Disney RHL (1989) Scuttle flies. Diptera: Phoridae, Genus Megaselia. Handb Identif Br Insects 10:1-155

Disney RHL (1994) Scuttle flies: the Phoridae. Chapman and Hall, London

Disney RHL, Durska E (2008) Conservation evaluation and the choice of faunal taxa to sample. Biodiv Conserv 17:449-451

Durska E (1996) The species composition and structure of scuttle fly communities (Diptera: Phoridae) in mature tree stands in pine forests at different stages of habitat degradation. Fragmenta Faunistica 39:267-285
Durska E (2001) Secondary succession of scuttle fly (Diptera: Phoridae) communities in moist pine forest in Białowieża forest. Fragmenta Faunistica 44:81-130

Durska E (2006) Diversity of the scuttle fly (Diptera: Phoridae) communities in the plantations of moist pine forests of the Białowieża Primeval Forest and the Tuchola Forest (Poland). Biodiv Conserv 15:385-393

Durska E (2009) The scuttle fly (Diptera, Phoridae) assemblages of pine plantations of the Biała forest (Poland). Entomol Fenn 20:170-178

Faccio SD (2003) Effects of ice storm-created gaps on forest breeding bird communities in central Vermont. For Ecol Manage 186:133-145

Fuller JR (2000) Influence of treefall gaps on distributions of breeding birds within interior old-growth stands in Białowieża forest, Poland. Condor 102:267-274

Germaine SS, Vessey SH, Capen DE (1997) Effects of small forest openings on the breeding bird community in a Vermont Hardwood forest. Condor 99:708-718

Giraudo AR, Matteucci SD, Alonso J, Herrera J, Abramson RR (2008) Comparing bird assemblages in large and small fragments of the Atlantic forest hotspots. Biodiv Conserv 17:1251-1265

Gotelli NJ, Colwell RK (2001) Quantifying biodiversity: procedures and pitfalls in the measurement and comparison of species richness. Ecol Lett 4:379-391

Greenberg CH, Lanham JD (2001) Breeding bird assemblages of hurricane-created gaps and adjacent closed canopy forest in the southern Appalachians. For Ecol Manage 154:251-260

Gregory RD, Gibbons DW, Donald PF (2004) Bird census and survey techniques. In: Sutherland WJ, Newton I, Green RE (eds) Bird ecology and conservation; a handbook of techniques. Oxford University Press, Oxford, pp 17-56

Gregory RD, Vorisek P, Van Strien A, Meyling AWG, Jiguet F, Fornasari L, Reif J, Chylarecki P, Burfield IJ (2007) Population trends of widespread woodland birds in Europe. Ibis 149(Suppl. 2):78-97

Grimbacher PS, Stork NE (2009) How do beetle assemblages respond to cyclonic disturbance of a fragmented tropical rainforest landscape? Oecologia 161:591-599

Hanewinkel M, Breidenbach J, Neeff T, Kublin E (2008) Seventyseven years of natural disturbances in a mountain forest areathe influence of storm, snow, and insect damage analysed with a long-term time series. Can J For Res 38:2249-2261

Hurlbert SH (1984) Pseudoreplication and the design of ecological field experiments. Ecol Monogr 54:187-211

Hutto RL, Gallo SM (2006) The effects of postfire salvage logging on cavity-nesting birds. Condor 108:817-831

Koivula MJ, Schmiegelow FKA (2007) Boreal woodpecker assemblages in recently burned forested landscapes in Alberta, Canada: effects of post-fire harvesting and burn severity. For Ecol Manage 242:606-618

Koivula M, Spence JR (2006) Effects of post-fire salvage logging on boreal mixed-wood ground beetle assemblages (Coleoptera, Carabidae). For Ecol Manage 236:102-112

Kolbin VA (2008) Effect of forest fires on the avifauna of the Northern Amur region. Russ J Ecol 39:398-404

Kuuluvainen T (2002) Natural variability of forests as a reference for restoring and managing biological diversity in boreal Fennoscandia. Silva Fenn 36:97-125

Lepš J, Šmilauer P (2003) Multivariate analysis of ecological data using CANOCO. Cambridge University Press, Cambridge

Lindenmayer DB, Noss RF (2006) Salvage logging, ecosystem processes, and biodiversity conservation. Conserv Biol 20: 949-958

Lindenmayer DB, Burton P, Franklin JF (2008) Salvage logging and its ecological consequences. Island Press, Washington 
Moning C, Müller J (2008) Environmental key factors and their thresholds for the avifauna of temperate montane forests. For Ecol Manage 256:1198-1208

Müller J, Brandl R (2009) Assessing biodiversity by remote sensing and ground survey in mountainous terrain: the potential of LiDAR to predict forest beetle assemblages. J Appl Ecol 46:897-905

Müller J, Reed N, Bussler H, Brandl R (2010) Learning from a "benign neglect strategy" in a national park: Response of saproxylic beetles to dead wood accumulation. Biol Conserv 143:2559-2569

Neumann M, Starlinger F (2001) The significance of different indices for stand structure and diversity in forests. For Ecol Manage 145:91-106

Niemelä J (1999) Management in relation to disturbance in the boreal forest. For Ecol Manage 115:127-134

Prescher S, Moretti M, Duelli P (2002) Scuttle flies (Diptera, Phoridae) in Castanea sativa forests in the southern Alps (Ticino, Switzerland), with thirteen species new to Switzerland. Mitteilungen der Schweizerischen Entomologischen Gesellschaft. Bull de la Société Entomologique Suisse 75:289-298

Ralph CJ, Sauer JR, Droege S (1995) Managing and monitoring birds using point counts: standards and applications. In: Ralph CJ, Sauer JR, Droege S (eds) Monitoring bird populations by point counts. USDA Forest Service, Gen. Tech. Rep. PSW-GTR-149, Albany, pp 161-168

Ribera I, Doledec S, Downie IS, Foster GN (2001) Effect of land disturbance and stress on species traits of ground beetle assemblages. Ecology 82:1112-1129

Schelhaas MJ, Nabuurs GJ, Schuck A (2003) Natural disturbances in the European forests in the 19th and 20th centuries. Glob Chang Biol 9:1620-1633

Schmitz H (1938-1958) Phoridae. In: Lindner E (ed) Die Fliegen der palaearktischen Region IV(7). Schweizerbart, Stuttgart

Schmitz H, Beyer E, Delage A (1974-1981) Phoridae (Fortsetzung). In: Lindner E (ed) Die Fliegen der palaearktischen Region IV(7). Schweizerbart, Stuttgart

Shorohova E, Kuuluvainen T, Kangur A, Jõgiste K (2009) Natural stand structures, disturbance regimes and successional dynamics in the Eurasian boreal forests: a review with special reference to Russian studies. Ann For Sci 66: art. no. 201

Skłodowski JJW (2006) Anthropogenic transformation of ground beetle assemblages (Coleoptera: Carabidae) in Białowieża forest, Poland: from primeval forests to managed woodlands of various ages. Entomol Fenn 17:296-314

Standovar T, Odor P, Aszalos R, Galhidy L (2006) Sensitivity of ground layer vegetation diversity descriptors in indicating forest naturalness. Commun Ecol 7:199-209

Szczepski JB, Kozłowski P (1953) Pomocnicze tabele ornitologiczne. Polish Scientific Publisher, Warsaw

Taboada A, Tarrega R, Calvo L, Marcos E, Marcos JA, Salgado JM (2010) Plant and carabid beetle species diversity in relation to forest type and structural heterogeneity. Eur J For Res 129:31-45

Tomiałojć L, Wesołowski T (2004) Diversity of the Białowieża Forest avifauna in space and time. J Ornithol 145:81-92

Venier LA, Pearce JL (2004) Birds as indicators of sustainable forest management. For Chron 80:61-66

Venier LA, Pearce JL (2007) Boreal forest landbirds in relation to forest composition, structure, and landscape: implications for forest management. Can J For Res 37:1214-1226

Wesołowski T (2005) Virtual conservation: how the European Union is turning a blind eye to its vanishing primeval forest. Conserv Biol 19:1349-1358

Wesolowski T, Rowiński P, Mitrus C, Czeszczewik D (2006) Breeding bird community of a primeval temperate forest (Bialowieza National Park, Poland) at the beginning of the 21st century. Acta Ornithol 41:55-70

Zajączkowski G, Dzierża B (2007) Analiza przestrzennego rozkładu rodzaju i stopnia uszkodzenia drzewostanów dla lasu ochronnego "Szast" oraz wybranych lasów gospodarczych na podstawie spektrostrefowych zdjęć lotniczych, danych z terenowej inwentaryzacji uszkodzeń drzewostanów oraz danych z III rewizji urządzania lasu wg stanu na 3 lipca 2002 r. Unpublished report, Research Forest Institute, Warsaw

Żmihorski M (2010) The effect of windthrow and its management on breeding bird communities in a managed forest. Biodiv Conserv 19:1871-1882 